\title{
Effect of fly ash characteristics on the behaviour of pastes prepared under varied brine conditions
}

\author{
Jabulani S. Mahlaba ${ }^{\text {a,b,* }}$, Elsabé P. Kearsley ${ }^{a}$, Richard A. Kruger ${ }^{c}$ \\ ${ }^{a}$ University of Pretoria, Civil Engineering, Pretoria 0002, South Africa \\ b SASOL Technology RE'D, Environmental Sciences and Engineering, Secunda, South Africa \\ ${ }^{\mathrm{c}}$ Richonne Consulting, P.O.Box 742, Somerset Mall, Cape Town, 7137, South Africa
}

\section{A R T I C L E I N F O}

\section{Article history:}

Received 25 January 2011

Accepted 10 April 2011

Available online $\mathrm{xxxx}$

\section{Keywords:}

Fly ash

Brine

Paste backfill

Strength development

\begin{abstract}
A B S T R A C T
To meet the escalating demand of energy more coal ash and brines are inevitably produced as byproducts. Large volumes of these wastes and increasing environmental awareness necessitate the development of more sustainable methods to mitigate the environmental footprint. Paste backfill is one of the potential solutions to keep the energy industry sustainable. The behaviour of pastes was investigated by strategically varying brine composition mixed with the two types of fly ash. The results showed that fly ash plays a more prominent role in the behaviour of pastes than brines. It is therefore imperative to consider both fly ash and brine characteristics i.e. constituents of paste for the development of an environmentally sound paste backfill practice. Technically there are numerous benefits in pursuing the proposed solution.
\end{abstract}

(c) 2011 Elsevier Ltd. All rights reserved.

\section{Introduction}

The ever-increasing energy demands necessitate combustion of more coal, which is the reliable source of energy worldwide. It is a fact that combustion of low-grade coal generates vast quantities of fly ash of which the global average utilisation is approximately $16 \%$ (Ahmaruzzaman, 2010). This leaves the remaining 420 million tons of fly ash requiring measures for disposal annually.

The scarcity of potable water as well as high water consumption during mineral and coal processing leads to the inevitable saline brine production. The management of industrial brines resulting from water recovery processes presents an environmental concern especially inland (Nassar et al., 2008; Souilah et al., 2004; Vedavyasan, 2001), where the option of oceanic disposal is often uneconomical (Ahmed et al., 2003; Nassar et al., 2008; Korngold et al., 2009). The variability of brines as well as failure to meet legal environmental requirements restricts their potential utilisation in applications such as crystallisation of marketable salts, and mixing water in concrete. Literature focuses on the detrimental impact of chlorides in reinforced concrete (Balonis et al., 2010; Neithalath and Jain, 2010; Arya et al., 1990; Barberon et al., 2005) and sulphates to explain concrete deterioration (Medvešček et al., 2006; Collepardi, 2003; Borsoi et al., 2009). These anions give rise to durability problems if they come from

\footnotetext{
* Corresponding author at: University of Pretoria, Civil Engineering, Pretoria 0002, South Africa. Tel.: +27 (0)17 6192500.

E-mail address: sam.mahlaba@sasol.com (J.S. Mahlaba).
}

the external environment such as the interaction of seawater with concrete.

The study to utilise seawater as mixing water in concrete produced stronger concrete than a control prepared with potable water (Akinkurolere et al., 2007; Taylor and Kuwairi, 1978). Mahlaba and Pretorius (2006) and Mahlaba (2007) indicated that, compared to water, brines have an advantageous effect on the workability of fly ash pastes. The major components in seawater are chloride, sodium, calcium and sulphate (Alahmad, 2010) which most saline brines have been reported to emulate (Ahmed et al., 2003; Ravizky and Nadav, 2007; Mooketsi et al., 2007; Koch, 2002). Furthermore, the use of $\mathrm{Cl}$-bearing compounds to accelerate strength development and improve mechanical properties is common practice in concrete production (Akinkurolere et al., 2007; Taylor and Kuwairi, 1978; Shi, 1996). $\mathrm{Na}_{2} \mathrm{SO}_{4}$ is used to accelerate pozzolanic reactions whereas gypsum $\left(\mathrm{CaSO}_{4} \cdot 2 \mathrm{H}_{2} \mathrm{O}\right)$ addition controls the setting of concrete (Shi, 1996; Odler, 2004).

Therefore management of both fly ash and brines pose a major environmental risk to surface water and land availability if not properly dealt with. However, the pozzolanic properties of fly ash make it suitable for utilisation in agriculture, waste treatment and cement extension (Shehata, 2001; Muriithi et al., 2011; Kruger and Surridge, 2009; Fester et al., 2008; Vadapalli et al., 2008).

Existing literature focuses on mine backfill with thickened tailings (Jewell and Fourie, 2006; Potvin et al., 2005; Benzaazoua et al., 1999) and rarely on water-based fly ash pastes (Steward and Slatter, 2009; Stropnik and Južnič, 1988; Naik et al., 2009). It was therefore scientifically justifiable to investigate the behaviour of 
pastes prepared with brines and fly ash; initial results indicated that contaminants are stabilised in paste (Ilgner, 2006; Mahlaba and Pretorius, 2006; Muntingh et al., 2009; Mahlaba et al., 2008). The current authors investigated the influence of industrial brines on the characteristics of fly ash pastes where it was demonstrated that brine chemistry dominates paste behaviour with a given fly ash type (Mahlaba et al., 2011). These findings suggest that codisposal of these wastes as a paste backfill material will provide an innovative solution which is environmentally less harmful than their individual disposal.

Paste properties (especially its rheology) are influenced by numerous factors of the materials used (Jewell and Fourie, 2006; Verburg, 2001). The present study sheds light on the influence of fly ash characteristics on the brine-based paste behaviour due to site specificity reported in literature (Jewell and Fourie, 2006; Verburg, 2001). Improved understanding of paste behaviour as a function of both fly ash and brine characteristics will potentially lead to the development of a sound backfill solution as well as geotechnical utilisation opportunities. This manuscript makes a significant contribution towards ensuring the sustainability of the coal processing industry.

\section{Materials}

\subsection{Brines}

Brines A and B originate from ion-exchange demineralisation (including regeneration chemicals) and thermal evaporation of water at a South African petrochemical plant, respectively. These industrial brines represent the worst case scenarios of brines from most desalination facilities in terms of chemical composition and salinity, and to a certain degree simulate seawater. The chemical composition of these brines and seawater is shown in Table 1.

\subsection{Fly ash}

Different fly ashes were collected from two South African power stations combusting different coal types to generate electricity using coal-fired boilers. The elemental and mineralogical composition of these fly ashes, namely, fly ashes A and B is provided in Table 2.

\subsection{Examination of physical properties}

It is well documented in literature that fly ash characteristics principally depend on coal type and combustion method. Finer ash particles are richer in the glassy phase and are more reactive while coarser fractions are richer in carbon (Ward and French, 2006; Nochaiya et al., 2009; Chancey et al., 2010). Spherical fly ash particles reduce friction between particles and improve workability at lower water demands in a paste (Campbell, 1999; Chindaprasirt et al., 2005). Moreover reduced water demand re-

Table 1

Chemical composition of brines A, B and seawater.

\begin{tabular}{lllll}
\hline Component & Unit & Brine A & Brine B & Seawater \\
\hline $\mathrm{pH}$ & - & 7.4 & 8.8 & $8.2-10.0$ \\
$\mathrm{EC}$ & $\mu \mathrm{S} / \mathrm{cm}$ & 70,400 & 124,000 & - \\
$\mathrm{Ca}^{2+}$ & $\mathrm{mg} / \mathrm{l}$ & 341 & 2100 & 500 \\
$\mathrm{Mg}^{2+}$ & $\mathrm{mg} / \mathrm{l}$ & 238 & 1550 & 1550 \\
$\mathrm{Na}^{+}$ & $\mathrm{mg} / \mathrm{l}$ & 19,227 & 21,000 & 12,000 \\
$\mathrm{Cl}^{-}$ & $\mathrm{mg} / \mathrm{l}$ & 14,668 & 34,300 & 22,000 \\
$\mathrm{SO}_{4}^{=}$ & $\mathrm{mg} / \mathrm{l}$ & 5931 & 15,200 & 3000 \\
$\mathrm{TDS}$ & $\mathrm{mg} / \mathrm{l}$ & 44,400 & 108,000 & $39,806-45,000$
\end{tabular}

\#TDS = total dissolved solids.
Table 2

Elemental and mineralogical composition of fly ashes A and B (\%).

\begin{tabular}{lcc}
\hline Component & Fly ash A & Fly ash B \\
\hline Elemental composition (\%) & & \\
$\mathrm{SiO}_{2}$ & 49.7 & 59.5 \\
$\mathrm{Al}_{2} \mathrm{O}_{3}$ & 26.2 & 28.5 \\
$\mathrm{Fe}_{2} \mathrm{O}_{3}$ & 2.7 & 5.9 \\
$\mathrm{CaO}$ & 10.5 & 2.3 \\
$\mathrm{MgO}$ & 2.1 & 0.4 \\
$\mathrm{SO}_{3}$ & 0.5 & 0.4 \\
$\mathrm{Na}_{2} \mathrm{O}$ & 0.7 & - \\
$\mathrm{K}_{2} \mathrm{O}$ & 0.9 & 1.0 \\
$\mathrm{TiO}_{2}$ & 1.5 & 1.3 \\
Loss on ignition (LOI) & 4.1 & - \\
Other & 0.9 & 0.7 \\
$\mathrm{Total}_{\text {Mineralogical phase }(\%)}$ & 99.8 & 100.0 \\
Mullite $\left(\mathrm{Al}_{6} \mathrm{Si}_{2} \mathrm{O}_{13}\right)$ & & \\
Quartz $\left(\alpha-\mathrm{SiO}_{2}\right)$ & 20.53 & 28.98 \\
Hematite $\left(\mathrm{Fe}_{2} \mathrm{O}_{3}\right)$ & 10.24 & 11.86 \\
Lime $(\mathrm{CaO})$ & 0.68 & 1.43 \\
Glassy phase & 2.22 & 0.37 \\
Total & 66.33 & 57.36 \\
& 100.0 & 100.0 \\
\hline
\end{tabular}

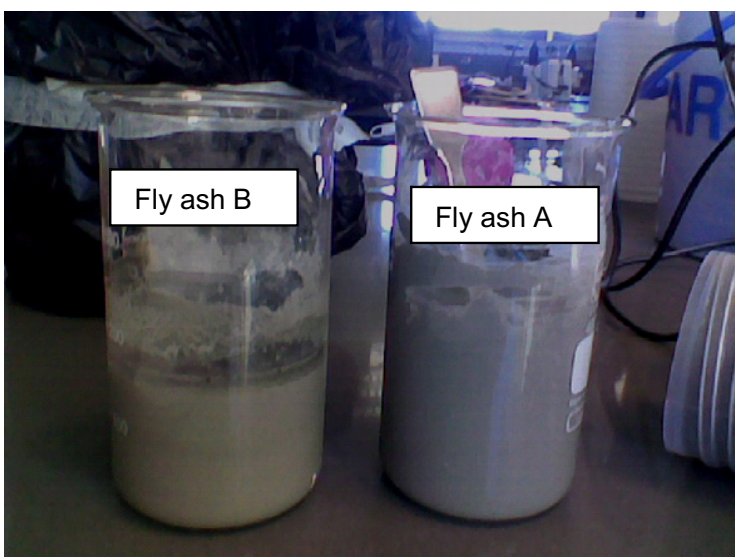

Fig. 1. Picture showing colour difference between fly ash A and B.

sults in a more cohesive paste with minimal bleed formation and low hydraulic conductivity; the cornerstones of good paste (Pagé and Spiratos, 2000; Chindaprasirt et al., 2005; Joshi et al., 1994).

It was considered necessary to discuss physical characteristics of fly ash in addition to chemical properties to enable better interpretation of paste behaviour. The fundamental physical characteristics of fly ash examined are colour, particle size distribution, and particle morphology.

\subsubsection{Colour}

There is a significant colour difference between the two fly ashes where fly ash A is greyish like ordinary cement and fly ash $B$ is brownish ${ }^{1}$ as depicted in Fig. 1. Such a difference can be assigned to an appreciably higher concentration of iron in fly ash $\mathrm{B}$ (Table 2) i.e. chemical composition.

\subsubsection{Particle morphology}

It is illustrated in Fig. 2 that the majority of particles in fly ash A has a spherical morphology while that of fly ash $B$ is rather irregular as depicted in Fig. 3. Therefore pastes prepared with fly ash A

\footnotetext{
${ }^{1}$ For interpretation of colour in Fig. 1, the reader is referred to the web version of this article.
} 

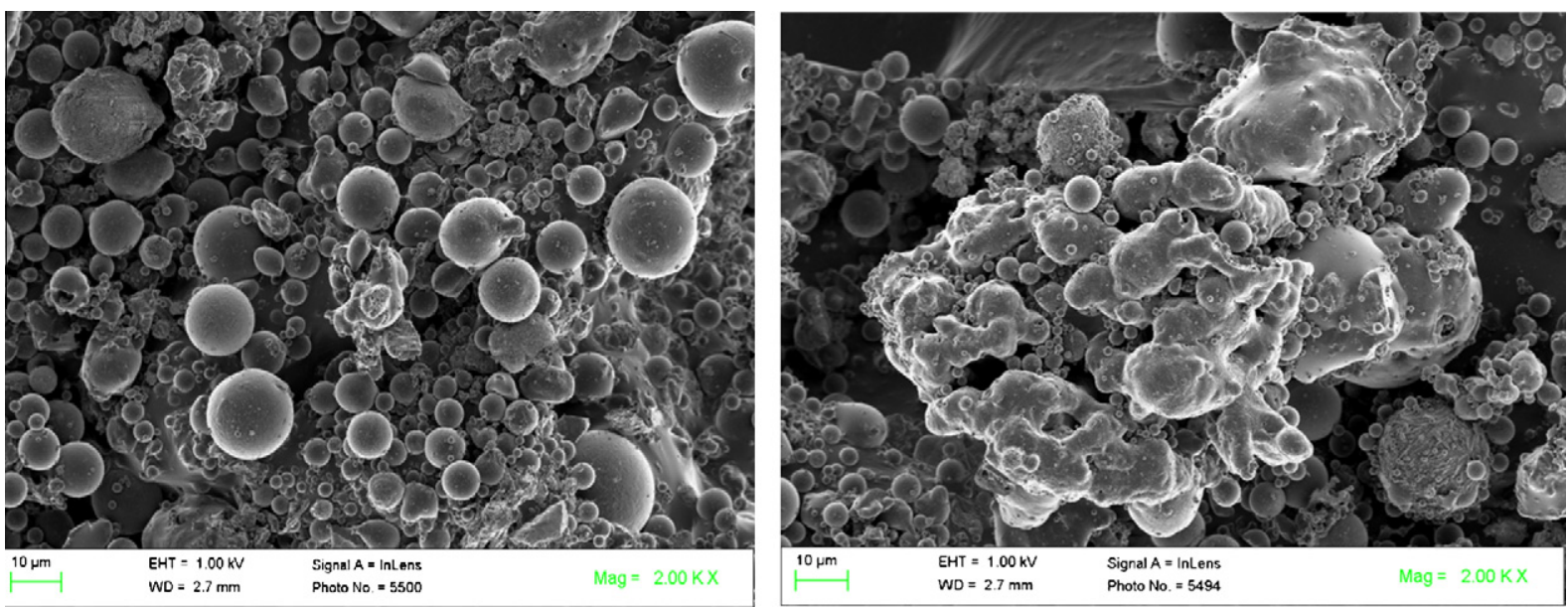

Fig. 2. Typical morphology of fly ash A particles.
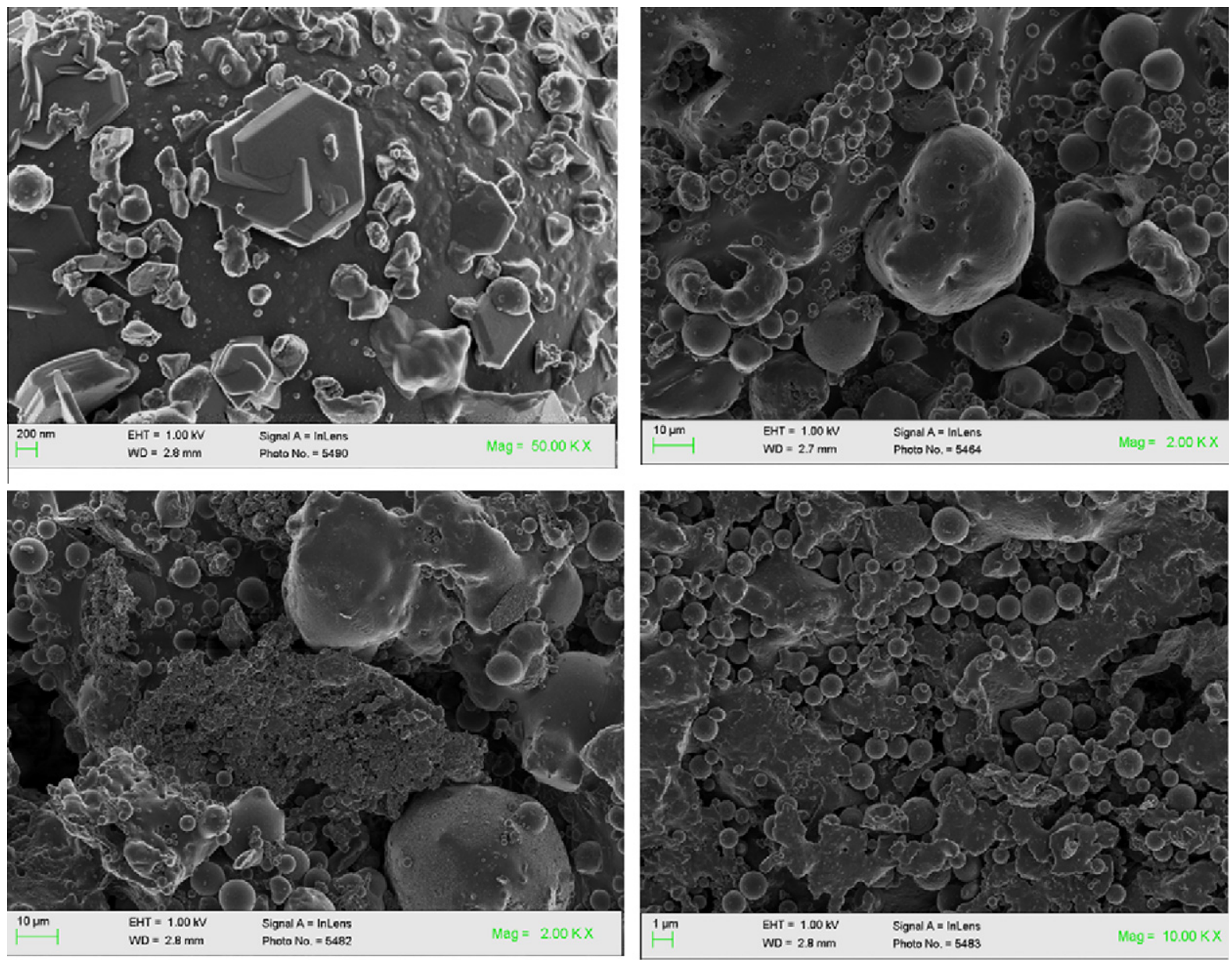

Fig. 3. Characteristic morphology of fly ash B particles.

are expected to be more workable and stronger than those containing fly ash B (Pagé and Spiratos, 2000; Chindaprasirt et al., 2005).

\subsubsection{Particle size distribution}

Particle size distribution (PSD) profiles of the two fly ashes were determined to indicate basic differences. From Fig. 4 the abundance of particles $<20 \mu \mathrm{m}$ in fly ash can be deduced, which, as a rule of thumb, must exceed $15 \%$ for a stable paste formation (Jewell and Fourie, 2006). It is evident that fly ash A has over $40 \%$ while fly ash $B$ has approximately $20 \%$ of particles below the threshold particle size, giving the former an advantage to form a better paste.

The PSD data were further classified into different size fractions according to ASTM D 422-63 as shown in Fig. 5. The abundance of clay-sized particles in fly ash A is almost twice that of fly ash B while that of silt-sized particles is $17 \%$ higher in the former. As expected the sand-sized particles are significantly higher in fly ash $\mathrm{B}$.

Please cite this article in press as: Mahlaba, J.S., et al. Effect of fly ash characteristics on the behaviour of pastes prepared under varied brine conditions. 


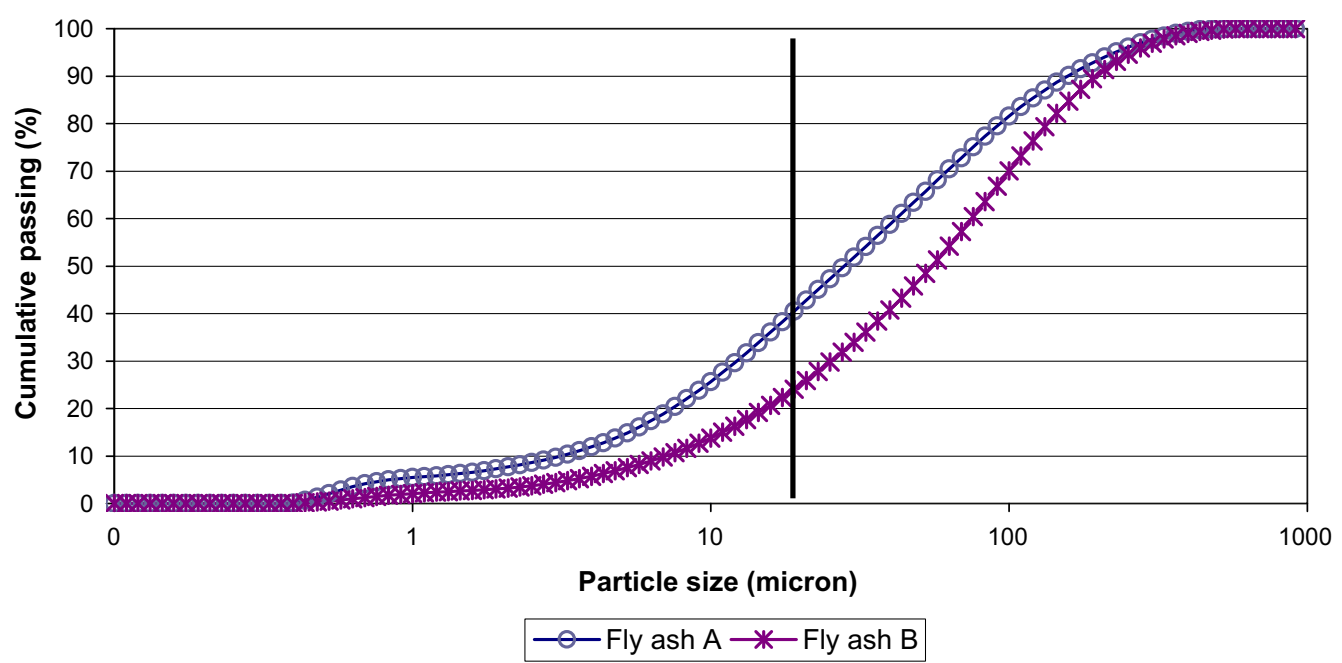

Fig. 4. Particle size distributions of the two fly ashes.

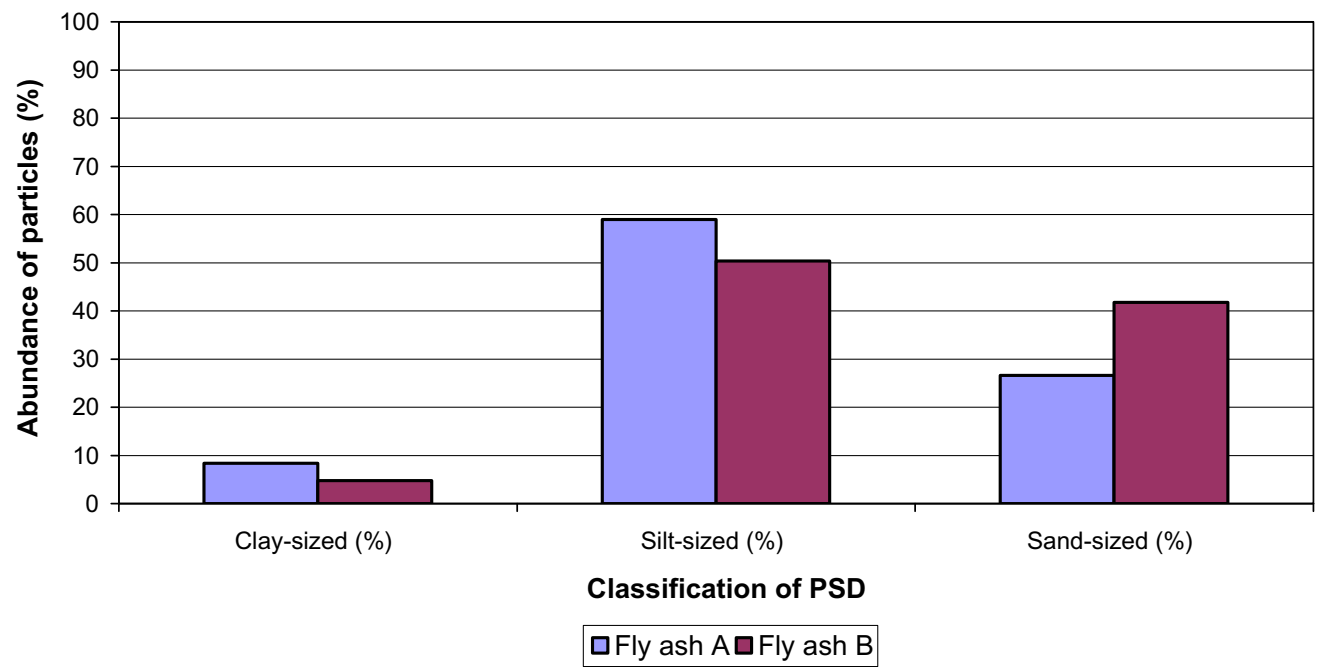

Fig. 5. Particle size distributions of the two fly ashes.

Thus fly ash B is coarser than fly ash A and according to literature finer particles are more reactive than coarser particles which are generally rich in unburned carbon (Chancey et al., 2010; Campbell, 1999; Mahlaba and Pretorius, 2006).

\section{Experimental}

The role of fly ash as a function of brine variability was studied where workability and compressive strength of paste were used as indicators of the effect. These parameters are essential to determine the suitability of cementitious materials for engineering applications. Naik et al. (2009) emphasise that quick settling of fly ash slurries induces workability challenges substantiated through rheology measurements in the study. Mahlaba and Pretorius (2006) previously reported that brine chemistry can be used to control the hardening of paste during its transportation and save on plasticisers.

\subsection{Yield stress}

Yield stress of fresh paste was measured after 15 min of maturation using an Anton Paar rheometer set at low vane speeds (Boger et al., 2008) to achieve reproducible data. Material proper- ties including those discussed in Section 2.3 affect rheological behaviour and maturation time of paste. For instance Naik et al. (2009) used a maturation time of $60 \mathrm{~min}$ in fly ash slurries they investigated.

\subsection{Unconfined compressive strength}

The paste specimens were cured for 28 days before determining the unconfined compressive strength (UCS). A pre-load of $10 \mathrm{~N}$ was first applied before data collection commenced at a compression rate of $2.5 \mathrm{~mm} / \mathrm{min}$ to failure (ASTM C109), using a Z050 Zwick Roell compression machine with $50 \mathrm{kN}$ capacity.

\subsection{Effect of fly ash properties}

The effect of fly ash properties on the paste behaviour was evaluated by subjecting two types of fly ash to varying brine conditions. Fly ashes were mixed with various amounts of brines A, B, and deionised water to make a series of pastes containing between $62 \%$ and $70 \%$ fly ash content by mass.

Brine salinity was previously identified as one of the important determinants of paste rheology and strength development (Mahlaba et al., 2011). The response of pastes containing these 
fly ashes to increasing salinity will reveal their influence on the resultant paste properties. Brine B was selected to study the effect of salinity on pastes containing the two fly ashes. The dilution of brine $\mathrm{B}$ was performed with deionised water to cover a wide range of salinity. The total dissolved solids (TDS) of these solutions were determined at $200{ }^{\circ} \mathrm{C}$. Yield stress and UCS were determined on pastes containing these solutions and 68\% fly ash (Mahlaba et al., 2008).

\section{Results and discussion}

The aim of using fly ash with different chemical properties was to verify whether ash chemistry influences the paste behaviour and test the applicability of results obtained here to similar operations. This section presents the results obtained for pastes containing the two fly ashes as a function of brine variance. The emphasis was placed on both the rheological and mechanical characteristics of the resultant pastes.

\subsection{Rheological behaviour}

The rheological results presented in Fig. 6 demonstrate that the workability of pastes prepared with fly ash B is not influenced by variability in brine composition. All pastes with fly ash $B$ gave a yield stress of approximately $40 \mathrm{~Pa}$. On the contrary, pastes derived from fly ash A with brine A and deionised water gave a yield stress of approximately $80 \mathrm{~Pa}$ which is twice that of pastes bearing fly ash B. A substantially higher yield stress of $210 \mathrm{~Pa}$ was achieved by paste containing fly ash A and brine B. Mahlaba et al. (2011) discovered that a salinity of brine must not exceed $60,000 \mathrm{mg} / \mathrm{l}$ for pastes prepared with fly ash A to remain pumpable with centrifugal pumps.

Fig. 7 also shows a negligible response of fly ash B bearing pastes to changes in brine salinity. In contrast, fly ash A pastes demonstrated an exponential increase in the yield stress when TDS in brine exceeded $40,000 \mathrm{mg} / \mathrm{l}$. The increase in the yield stress as a function of brine salinity for pastes derived from fly ash A indicates the occurrence of early hardening reactions (Campbell, 1999). This behaviour was not exhibited by pastes bearing fly ash B which is indicative of poor reactivity and thus less strength development is anticipated for pastes containing fly ash B.

\subsection{Unconfined compressive strength}

The UCS results of pastes containing different fly ash types exposed to varying brines are depicted in Fig. 8. It is illustrated that fly ash A responded to different brines whereas fly ash B was less reactive within 28 days. The UCS of fly ash B pastes was below

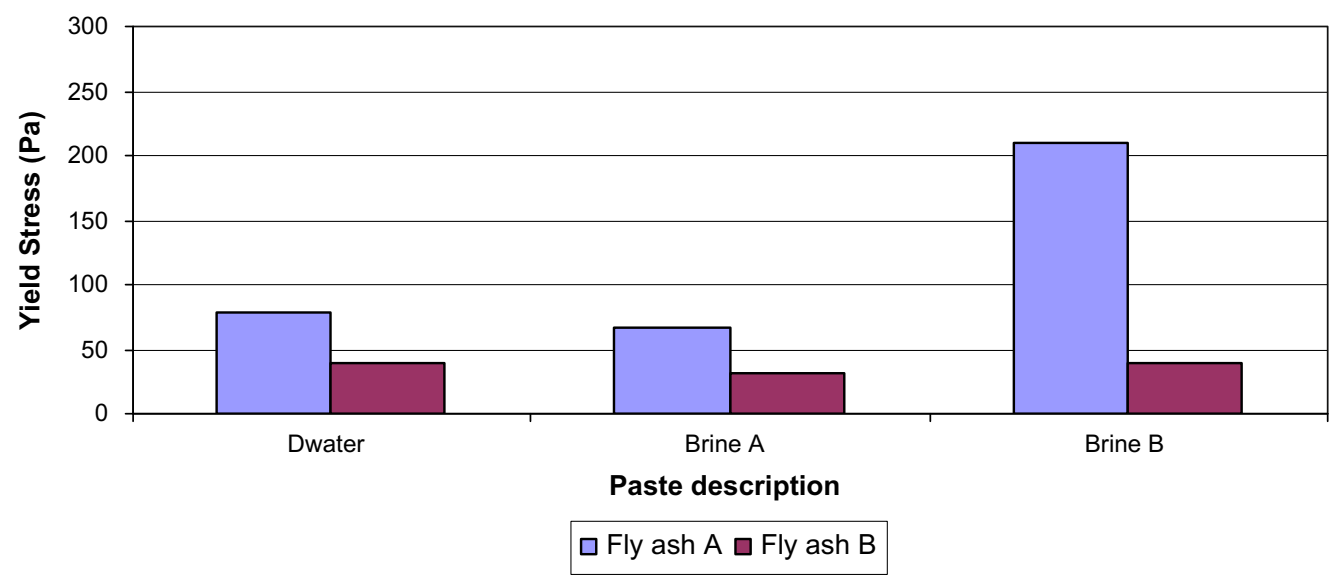

Fig. 6. Effect of fly ash properties on workability.

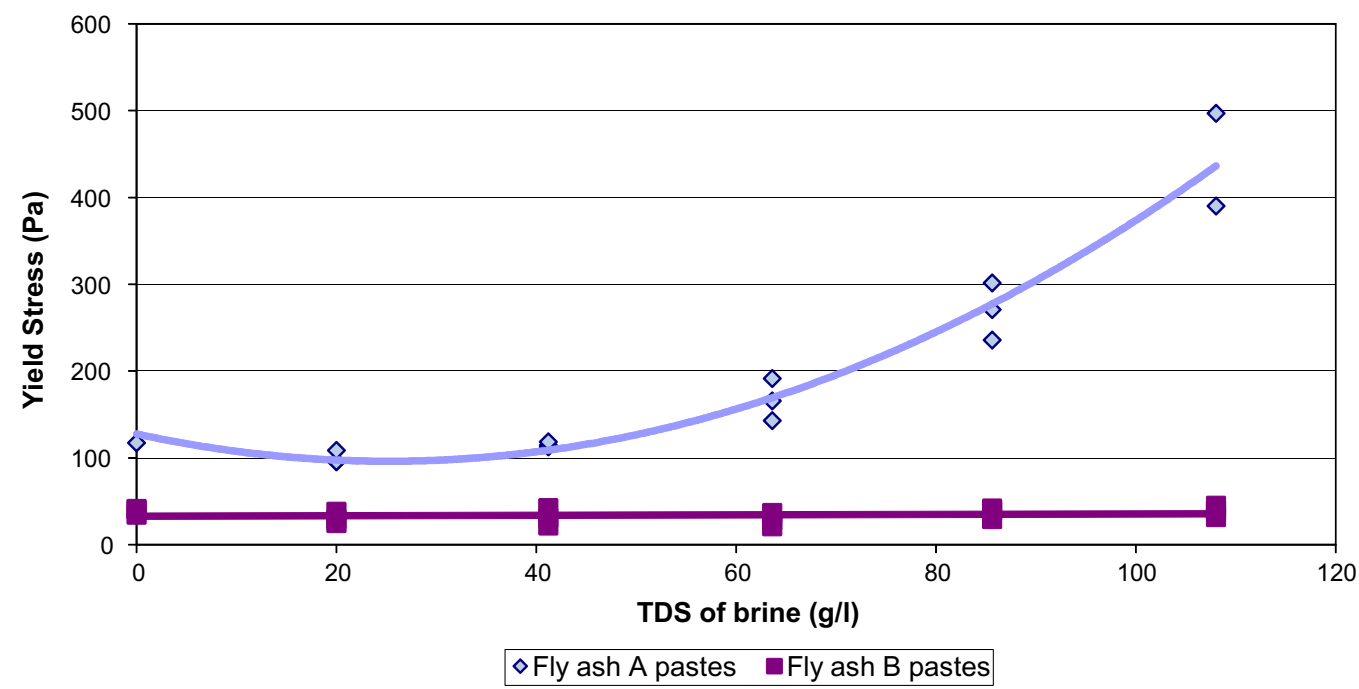

Fig. 7. Rheological response of pastes to salinity per fly ash type. 


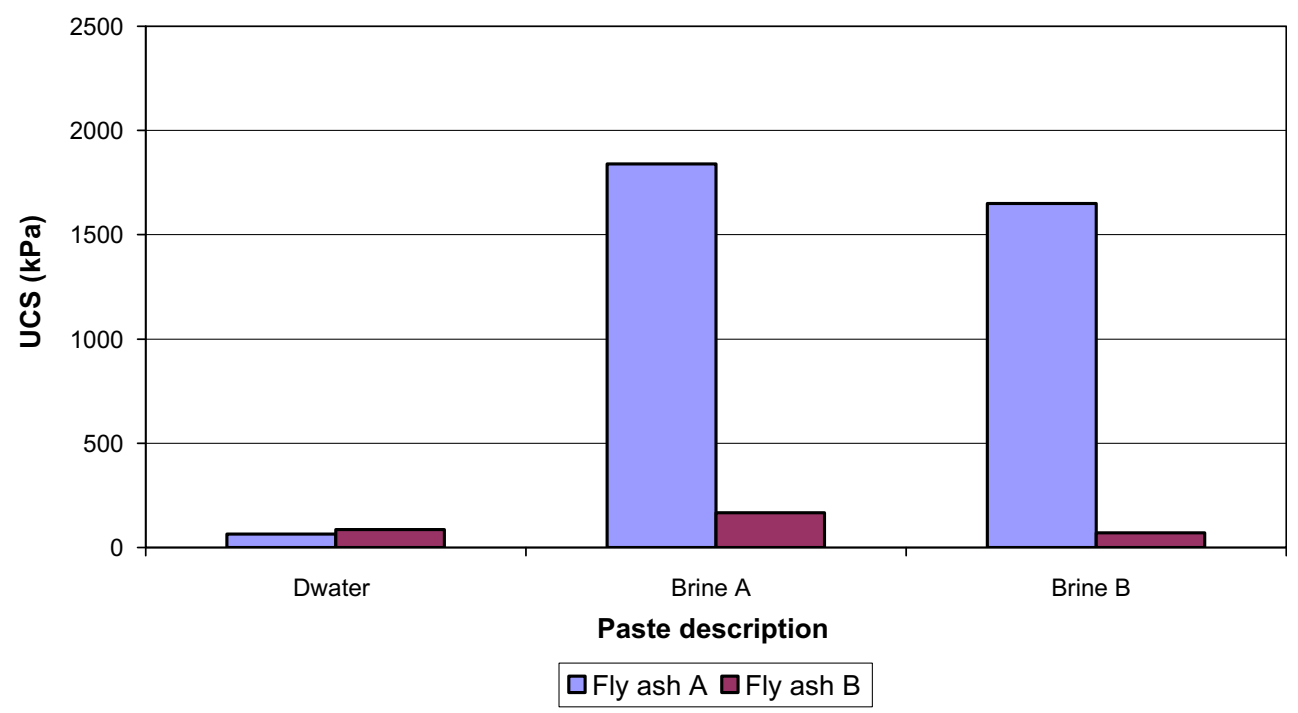

Fig. 8. Influence of fly ash on the strength development of pastes prepared with varied brines.

$200 \mathrm{kPa}$ whereas pastes containing fly ash A reached $1840 \mathrm{kPa}$ and $1650 \mathrm{kPa}$ with brine $\mathrm{A}$ and brine $\mathrm{B}$, respectively. The results obtained with fly ash A bearing pastes suggest that brine chemistry affects the mechanical properties of paste, not necessarily according to salinity (Mahlaba et al., 2011). Pastes prepared with brines and fly ash A significantly exceeded a minimum UCS of $200 \mathrm{kPa}$ suggested by Potvin et al. (2005) for mine backfill. Mahlaba (2007) showed that the $\mathrm{pH}$ of paste remained high even when acidic brines were used due to high alkalinity of fly ash which agrees with its use of neutralising acid mine drainage (Vadapalli et al., 2008; Gitari et al., 2006; Shang and Wang, 2005; Benzaazoua et al., 2002; Fester et al., 2008).

The distinction exhibited by two fly ashes was attributed to the mineralogical differences especially lime deficiency and lower content of the amorphous phase in fly ash B (Ward and French, 2006; Donahoe, 2004). Furthermore, higher degree of fineness and sphericity in fly ash A contributes to its superior performance on desired paste characteristics. Nevertheless, the use of additives such as lime and cement can ameliorate the reactivity of fly ash B for paste backfill systems (Giergiczny, 2004; Shi, 1996).

This study has clearly shown the benefits of utilising brine instead of water in fly ash paste backfill applications. The ultimate goal and benefit to stakeholders is ensuring water conservation and sustainable energy generation from coal.

\section{Conclusions and recommendations}

The important findings of this study reveal that:

- Paste backfill of brines with fly ash is possible if suitable materials are used.

- The paste properties are site-specific and generalisation may be too risky and inaccurate.

- Paste behaviour is better explained by considering chemical, mineralogical and physical properties of the fly ash in addition to brine chemistry of the mixing water.

- Fly ash characteristics seem to play a more important role than brine chemistry because fly ash is the major component and provides stabilisation of contaminants in the paste disposal application.

This manuscript was extracted from the PhD thesis of the lead author. Future research will have to investigate ways of ameliorat- ing the characteristics of fly ash B to achieve similar paste properties as fly ash A. The leachability of resultant pastes will be a critical factor in determining the environmental impact of this promising application.

\section{Acknowledgements}

The authors would like to thank SASOL Technology R\&D (Pty.) Ltd. for sponsoring this project and granting permission to publish this work. The University of Pretoria and Richonne Consulting are highly acknowledged for the support and healthy debates which led to the success of the project. Ms. Tracey Laban is thanked for kindly providing final language editing on the manuscript. Constructive comments from reviewers and the editor of Minerals Engineering are acknowledged in helping improve the original manuscript. This paper emanated from the PhD thesis of the lead author.

\section{References}

Ahmaruzzaman, M., 2010. A review on the utilization of fly ash. Progress in Energy and Combustion Science 36, 327-363.

Ahmed, M. Arakel, A, Hoey, D. Thumarukudy, M.R, Goosen, M.F.A, Al-Haddabi, M. Al-Belushi, A., 2003. Feasibility of salt production from inland RO desalination plant reject brine: a case study. Desalination 158, 109-117.

Alahmad, M., 2010. Prediction of performance of sea water reverse osmosis units. Desalination 261, 131-137.

Akinkurolere, O.O., Jiang, C., Shobola, O.M., 2007. The influence of salt water on the compressive strength of concrete. Journal of Engineering and Applied Sciences 2 (2), 412-415.

Arya, C., Buenfeld, N.R., Newman, J.B., 1990. Factors influencing chloride-binding in concrete. Cement and Concrete Research 20, 291300.

Balonis, M., Lothenbach, B., Le Saout, G., Glasser, F.P., 2010. Impact of chloride on the mineralogy of hydrated Portland cement systems. Cement and Concrete Research 40, 1009-1022.

Barberon, F., Barghel-Bouny, V., Zanni, B., Bresson, H., de la Caillerie, J.-B., Malosse L., Gan, Z., 2005. Interaction between chloride and cement-paste materials. Magnetic Resonance Imaging 23, 267-272.

Benzaazoua, M., Belem, T., Bussiére, B., 2002. Chemical factors that influence the performance of mine sulphidic paste backfill. Cement and Concrete Research 32, 1133-1144.

Benzaazoua, M., Ouellet, J., Servant, S., Newman, P., Verburg, R., 1999. Cementitious backfill with high sulphur content: physical, chemical, and mineralogical characterization. Cement and Concrete Research 29, 719-725.

Boger, D.V., Scales, P.J., Sofra, F., 2008. Paste and thickened tailings and the impact on the development of new rheological techniques. In: Proc., Paste 2008, 11th Seminar on Paste and Thickened Tailings, Kasane, Botswana, 2008.

Borsoi, A., Collepardi, M., Collepardi, S., Troli, R., 2009. Influence of fly ashes on the drying shrinkage of superplasticised concretes in the presence of SRA. In: Proc., The 9th CANMET/ACI International Conference on Superplasticisers and other 
Chemical Admixture in Concrete, Seville, Spain, 12-16 October, 2009, pp 287296.

Campbell, A.E., 1999. Chemical, Physical and Mineralogical Properties Associated with the Hardening of some South African Fly Ashes. MSc Dissertation, University of Cape Town. South Africa.

Chancey, R.T., Stutzman, P., Juenger, M.C.G., Fowler, D.W., 2010. Comprehensive phase characterisation of crystalline and amorphous phases of a Class F fly ash. Cement and Concrete Research 40, 146-156.

Chindaprasirt, P., Jaturapitakkul, C., Sinsiri, T., 2005. Effect of fly ash fineness on compressive strength and pore size of blended cement paste. Cement and Concrete Composites 27, 425-428.

Collepardi, M., 2003. A state-of-the-art review on delayed ettringite attack on concrete. Cement and Concrete Composites 25 (4-5), 401-407.

Donahoe, R.J., 2004. Secondary mineral formation in coal combustion byproduct disposal facilities: implications for trace element sequestration. In: Gieré, R., Stille, P. (Eds.), Energy, Waste and the Environmental: a Geochemical Perspective. Geological Society, London, Special Publications 236, pp. 641658.

Fester, V.G., Slatter, P.T., Vadapalli, V.R.K., Petrik, L.F., Use of fly ash to treat acid mine drainage before use in backfill. In: Proc., Paste 2008, 11th Seminar on Paste and Thickened Tailings, Kasane, Botswana, 5-9 May, 2008.

Giergiczny, Z., 2004. Effect of some additives on the reactions in fly ash- $\mathrm{Ca}(\mathrm{OH})_{2}$ system. Journal of Thermal Analysis and Calorimetry 76, 747-754.

Gitari, M.W., Petrik, L.F., Etchebers, O., Key, L., Iwuoha, E., Okujeni, C., 2006 Treatment of acid mine drainage with fly ash: removal of contaminants and trace elements. Journal of Environmental Science and Health Part A 41, 17291747.

Ilgner, H.J., 2006. Mine backfill. In: Jewell, Fourie (Eds.), Rheological Concepts, Paste and Thickened Tailings - A Guide, second ed. Australian Centre for Geomechanics, Perth, Australia, pp. 170-178.

Jewell, R.J., Fourie, A.B., 2006. Paste and Thickened Tailings - A Guide, second ed. Australia Centre for Geomechanics, Perth, Western Australia.

Joshi, R.C., Hettiaratchi, J.P.A., Achari, G., 1994. Properties of modified Alberta fly ash in relation to utilization in waste management applications. Canadian Journal of Civil Engineering 21, 419-426.

Koch, E.W., 2002. An Investigation of the Chemistry Involved in the Mixing of an Industrial Effluent with Fine Ash. MSc Thesis, University of Stellenbosch. South Africa.

Korngold, E., Aronov, L., Daltrophe, N., 2009. Electrodialysis of brine solutions discharged from an RO plant. Desalination 242, 215

Kruger, R.A., Surridge, A.K.J., 2009. Predicting the efficacy of fly ash as a soil ameliorant. In: Proc., World of Coal Ash Conference, 4-7 May, 2009, Lexington, USA. <http://www.flyash.info/>.

Mahlaba, J.S., 2007. Evaluation of paste technology to co-dispose of ash and brines at Sasol Synfuels complex. MSc (Eng.) Dissertation, University of the Witwatersrand, South Africa.

Mahlaba, J.S. Kearsley, E.P. Kruger, R.A. Pretorius, P.C., 2011. The evaluation of industrial brines rich in $\mathrm{SO}_{4}^{=}$and $\mathrm{Cl}^{-}$on fly ash pastes to expand brine utilisation. Coal Combustion and Gasification Products (in press).

Mahlaba, J.S., Pretorius, P.C., Augustyn, M.P., 2008. Influence of admixtures on paste behaviour and the role of surface area on remobilisation. In: Proc., Paste 2008, 11th Seminar on Paste and Thickened Tailings, Kasane, Botswana, 5-9 May, 2008.

Mahlaba, J.S., Pretorius, P.C., 2006. Exploring paste technology as a co-disposa option for fly ash and brines. In Proc., Paste 2006, 9th International Seminar on Paste and Thickened Tailings, Limerick, Ireland, 3-7 April, 2006.

Medvešček, S., Gabrovšek, R., Kaučič, V., Meden, A., 2006. Hydration products in water suspension of Portland cement containing carbonates of various solubility. Acta Chimica Slovenica 53, 172-179.
Mooketsi, O.I., Ginster, M., Matjie, R.H., Riedel, K.J., 2007. Leachate characteristics of ash residues from laboratory-scale brine encapsulation simulation process. World of Coal Ash (WOCA), Kentucky, USA.

Muntingh, Y., Mahlaba, J.S., Pretorius, P.C., 2009., Utilising fly ash as a salt sink media through pasting with industrial brines. In: Proc., The World Congress on Engineering 2009, vol. 1, July 1-3, London, UK.

Muriithi, N.G., Gitari, W.M., Petrik, L.F., Ndungu, P.M., 2011. Carbonation of brine impacted fractionated coal fly ash: implications for $\mathrm{CO}_{2}$ sequestration. Journal of Environmental Management 92 (3), 655-664.

Naik, H.K., Mishra, M.K., Karanam, U.M., 2009. Rheological characteristics of fly ash slurry at varying temperature with and without an additive. In: 2009 World of Coal Ash (WOCA), Lexington, USA. <http://flyash.info/>.

Nassar, M.K.K., El-Damak, R.M., Ghanem, A.H.M., 2008. Impact of desalination plants brine injection wells on coastal aquifers. Environmental Geology 54, 445-454.

Neithalath, N., Jain, J., 2010. Relating rapid chloride transport parameters of concretes to microstructural features extracted from electrical impedance. Cement and Concrete Research 40, 1041-1051.

Nochaiya, T., Wongkeo, W., Primraska, K., Chaipanich, A., 2009. Microstructural, physical and thermal analyses of Portland cement-fly ash-calcium hydroxide blended pastes. Journal of Thermal Analysis and Calorimetry. doi: 10.1007/ s10973-009-0491-8.

Odler, I., 2004. Hydration, setting and hardening of Portland cement. In: Hewlett, P.C. (Ed.), Lea's Cement and Concrete Chemistry, fourth ed. ButterworthHeinemann, pp. 272.

Pagé, M., Spiratos, N., 2000. The role of superplasticizers in the development of environmentally-friendly concrete. In: Presented at "CANMET/ACI International Symposium on Concrete Technology for Sustainable Development." Canada, April 2000.

Potvin, Y., Thomas, E., Fourie, A.B., 2005. Handbook on Mine Fill. Australia Centre for Geomechanics, Australia.

Ravizky, A., Nadav, N., 2007. Salt production by the evaporation of SWRO brine in Eilat: a success story. Desalination 205, 374-379.

Shang, J.Q., Wang, H., 2005. Coal Fly Ash Contaminant Barrier for Reactive Mine Tailings. <http://www.flyash.info/2005/52sha.pdf> (cited 25.01.07).

Shehata, M.H., 2001. The Effects of Fly Ash and Silica Fume on Alkali Silica Reaction in Concrete. PhD Thesis, University of Toronto, Canada.

Shi, C., 1996. Early microstructure development of activated lime-fly ash pastes. Cement and Concrete Research 26 (9), 1351-1359.

Souilah, O., Akretche, D.E., Amara, M., 2004. Water reuse of an industrial effluent by means of electrodeionisation. Desalination 167, 49-54.

Steward, N.R., Slatter, P., 2009. The transport of fly ash pastes through pipelines. Australian Bulk Handling Review: July/August 2009.

Stropnik, B., Južnič, K., 1988. Thick suspension technology for fly ash transportation and disposal at a coal fired power plant. International Journal of Environmental Studies 33, 259-260.

Taylor, M.A., Kuwairi, M., 1978. Effects of ocean salts on the compressive strength of concrete. Cement and Concrete Research 8, 491-500.

Vadapalli, V.R.K., Klink, M.J., Etchebers, O., Petrik, L.F., Gitari, W., White, R.A., Key, D., Iwuoha, E., 2008. Neutralisation of acid mine drainage using fly ash, and strength development of the resulting solid residues. South African Journal of Science 104, 317-322.

Vedavyasan, C.V., 2001. Combating brine disposal under various scenarios. Desalination 139, 419-421.

Verburg, R.B.M., 2001. Use of paste technology for tailings disposal: potential environmental benefits and requirements for geochemical characterisation. In: IMWA Symposium 2001.

Ward, C.R., French, D., 2006. Determination of glass content and estimation of glass composition in fly ash using quantitative X-ray diffractometry. Fuel 85, 22682277. 